\title{
Synthesis and Biological Properties of Polymer Immunoadjuvants
}

\author{
Hai-Quan MAO, Ren-Xi ZHuo, ${ }^{*}$ and Chang-Lie FAN \\ Department of Chemistry, Wuhan University, \\ Wuhan 430072, China
}

(Received October 1, 1992)

\begin{abstract}
New biodegradable and biocompatible polyphosphate based on L-Tyr-L-Tyr or L-Ser-L-Tyr dipeptide as the recurring units were synthesized. One of these polyphosphates was chosen for the study of adjuvanticity in conjunction with the soluble antigen extracted from adult Schistosoma japonicum $(\mathrm{SjAg})$. The preliminary results show that, when measuring the serum antibody response to $\mathrm{SjAg}$ in female mice over 10 weeks, the polyphosphate (I) exhibited strong adjuvant activity.
\end{abstract}

KEY WORDS Polyphosphate / Immunoadjuvant / Synthesis / Tyrosine /

Modern synthetic, biochemical, and recombinant techniques have permitted the creation of increasingly pure polypeptide antigens to induce desired specific immune responses. But unfortunately, the small peptide antigens are generally weak immunogens. Therefore, the new generation of vaccines requires the use of strong adjuvants to raise the antibody responses to levels which will ensure protection against infectious disease.

The ideal adjuvant for human vaccines should be nontoxic, easily metabolized, stable in the absense of refrigeration and effective in accomplishing its desired goal. To date, there is no adjuvant that accomplishes all of these objectives. Of the adjuvants being studied, the majority of natural and synthetic adjuvants exhibit side effects. Only alum is licensed for use in human vaccine, but it is far from ideal. It may induce the formation of granuloma at the injection site and hypersensitive reactions. It is not always effective, increases cellmediated immunity only slightly if at all, as it cannot be lyophilized, it requires refrigerated storage. $^{1}$

It is known that the sustained release of antigen from a polymeric delivery device enhances its antibody response. ${ }^{2}$ It would be expected that when an antigen is introduced into a biodegradable polymer system with adjuvant properties, the antibody responses could be much higher. Kohn et al. ${ }^{3}$ first reported the synthesis and adjuvanticity of poly(Z-L-Tyr-L-Tyr-Hex-iminocarbonate), which was found to enhance the antigenicity of bovine serum albumin (BSA) in mice.

The fact that many hydrophobic and surface active substances can augment immune response $^{1}$ implies that compounds with hydrophobic or amphiphilic structures tend to have immunoadjuvanticity. In view of the known adjuvanticity of L-tyrosine derivatives ${ }^{3}$ and good biocompatibility, biodegradability of polyphosphate, ${ }^{4,5}$ we designed and synthesized a series of new polyphosphates with L-Tyr-LTyr or L-Ser-L-Tyr dipeptide as the recurring units. The chemical structures of these polyphosphates are shown in Figure 1. The

* To whom correspondence should be addressed. 


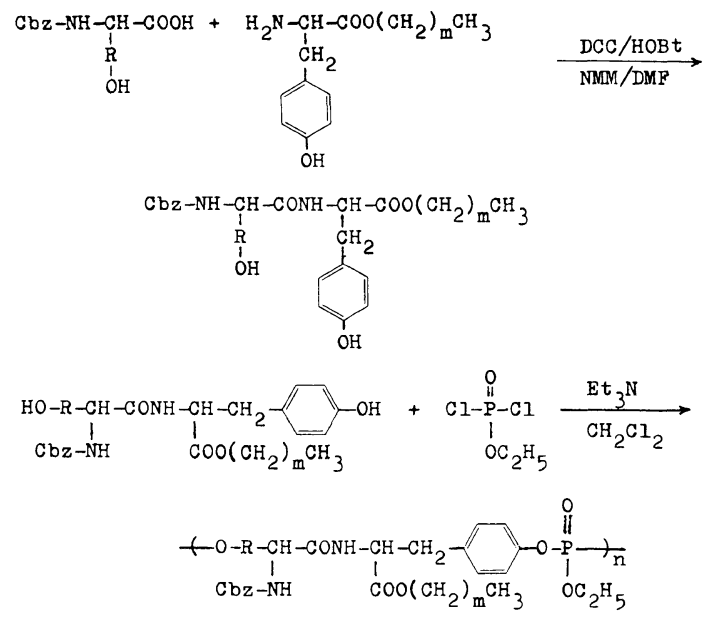

\begin{tabular}{|c|c|c|c|}
\hline Dipeptide ${ }^{\circ}$ & Polyphosphate & R & m \\
\hline CTTH & I & $-\mathrm{CH}_{2}-$ & 5 \\
\hline $\mathrm{CSTH}$ & $\mathbb{I}$ & $-\mathrm{CH}_{2}-$ & 5 \\
\hline CTTP & III & $-\mathrm{CH}_{2}-$ & 15 \\
\hline CSTP & N & $-\mathrm{CH}_{2}-$ & 15 \\
\hline CTTS & V & $-\mathrm{CH}_{2}$ & 17 \\
\hline CSTS & VI & $-\mathrm{CH}_{2}-$ & 17 \\
\hline
\end{tabular}

Figure 1. Synthetic scheme of polyphosphates. * CTTP, $\mathrm{N}$-benzyloxycarbonyl-L-tyrosyl-L-tyrosine palmityl ester; CSTP, $N$-benzyloxycarbonyl-L-seryl-L-tyrosine palmityl ester; CTTS, $N$-benzyloxycarbonyl-L-tyrosyl-L-tyrosine stearyl ester; CSTS, $N$-benzyloxycarbonyl-L-seryl-L-tyrosine stearyl ester.

stearyl or palmityl side chain will make the polyphosphates more hydrophobic, and the incorporation of serine residue into the polymer backbone chain will increase the hydrophilicity of the backbone. One of these polyphosphates has been used for the study of adjuvanticity in conjunction with the soluble antigen extracted from adult Schistosoma japonicum $(\mathrm{SjAg})$.

\section{EXPERIMENTAL}

\section{Synthesis and Characterization}

Materials and Apparatus. Tyrosine hexyl ester hydrochloride (Tyr-Hex-HCl), N-hydroxybenzotriazole (HOBt), and ethyl phosphodichloridate were prepared according to literature 6, 7, and 8, respectively. Triethylamine $\left(\mathrm{Et}_{3} \mathrm{~N}\right), \mathrm{N}$-methylmorphorine (NMM), dichloromethane, and dimethylformamide (DMF) were dried and redistilled before use. Dicyclohexylcarbodiimide (DCC) was purified by redistillation.

Gel permeation chromatography (GPC) was performed on a Shimadzu LC-4A high pressure liquid chromatography (HPLC) system. Tetrahydrofuran (THF) was used to elute the sample through HSG20 polystyrene column $(10 \mu \mathrm{m})$ $\left(1 \mathrm{ml} \mathrm{min}^{-1}, 25^{\circ} \mathrm{C}\right)$. The detection was done at $280 \mathrm{~nm}$ (UV detector). The system was calibrated with monodispersive polystyrene standards. Fourier transform infrared spectroscopy (FT-IR) was performed on a Nicolet 170SX machine (KBr plate). Proton nuclear magnetic resonance spectra were recorded on a FX-90Q instrument $(90 \mathrm{MHz}$, in deuterated chloroform). Elemental analyses were determined on Carlo Erba 1106 model instrument.

Synthesis of Dipeptide Monomers. To a cold solution $\left(0^{\circ} \mathrm{C}\right)$ of $N-\mathrm{Cbz}-\operatorname{Ser}(2.39 \mathrm{~g}, 10 \mathrm{mmol})$, Tyr-Hex-HCl (3.02 g, $10 \mathrm{mmol}), \mathrm{HOBt}(3.06 \mathrm{~g}$, $20 \mathrm{mmol})$ and NMM $(1.1 \mathrm{ml}, 10 \mathrm{mmol})$ in $45 \mathrm{ml}$ DMF, DCC $(2.27 \mathrm{~g}, 11 \mathrm{mmol})$ was added. The reaction mixture was stirred for $24 \mathrm{~h}$ at room temperature, then filtered, the filtrate was evaporated to dryness, the residue was redissolved in EtAc, washed with $1 N \mathrm{HCl}$ $(50 \mathrm{ml} \times 3), 1 \mathrm{~N} \mathrm{NH}_{4} \mathrm{OH}(50 \mathrm{ml} \times 3)$, saturated $\mathrm{NaCl}$ solution $(50 \mathrm{ml} \times 3)$, and dried with anhydrous $\mathrm{Na}_{2} \mathrm{SO}_{4}$, evaporated to dryness, the crude product was purified by flash chromatography using EtAc-MeOH-hexane (20:1: 10) as eluent, then was recrystallized twice, $\mathrm{N}$-Benzyloxycarbonyl-L-seryl-L-tyrosine hexyl ester (CSTH) was obtained as white powder, yield $3.5 \mathrm{~g}(72 \%)$. The other five dipeptides obtained as white powders were prepared according to the same procedure (Figure 1).

Synthesis of the Polyphosphates. To a cold 
solution $\left(0^{\circ} \mathrm{C}\right)$ of $N$-Benzyloxycarbonyl-Ltyrosyl-L-tyrosine hexyl ester (CTTH) $(1.125 \mathrm{~g}$, $2 \mathrm{mmol})$ and triethylamine $(0.56 \mathrm{ml}, 4 \mathrm{mmol})$ in $15 \mathrm{ml} \mathrm{CH}_{2} \mathrm{Cl}_{2}$, ethyl phosphodichloridate $(0.326 \mathrm{~g}, 2 \mathrm{mmol})$ in $10 \mathrm{ml} \mathrm{CH}_{2} \mathrm{Cl}_{2}$ was added dropwise, the reaction was stirred for $24 \mathrm{~h}$ at room temperature. The solution was washed with saturated $\mathrm{NaCl}$ solution $(20 \mathrm{ml} \times 3)$, dried with anhydrous $\mathrm{Na}_{2} \mathrm{SO}_{4}$ and evaporated to dryness. The residue was dissolved in methanol and reprecipitated in ether, the polyphosphate (I) was dried under vaccum, and obtained as yellowish powder, yield $0.82 \mathrm{~g}(63 \%)$.

By the same method, polyphosphates (II) - (VI) were obtained.

\section{In Vitro Degradation Study of the Polyphos- phates}

In Different $\mathrm{pH}$ Media. In vitro degradation studies were carried out by adding $100 \mathrm{mg}$ of the samples in $10 \mathrm{ml}$ distilled water which was adjusted to a given $\mathrm{pH}$ with dilute $\mathrm{NaOH}$ or $\mathrm{HCl}$ solution. The $\mathrm{pH}$ values of the suspension were recorded on $\mathrm{PH} / \mathrm{ISE}$ acidimeter (ORION SA720) at regular intervals $\left(20^{\circ} \mathrm{C}\right)$.

In Phosphate Buffered Saline (PBS). The tests were conducted by placing disc samples in $20 \mathrm{ml} 0.1 \mathrm{M} \mathrm{pH} 7.4 \mathrm{PBS}$ at $37^{\circ} \mathrm{C}$. The disc samples were fabricated by compression molding at room temperature and a pressure of $400 \mathrm{MPa}$. The discs were $11 \mathrm{~mm}$ in diameter, approximate $1.5 \mathrm{~mm}$ in thickness, and about $200 \mathrm{mg}$ in weight. The samples were removed after 10 days, dried to constant weight under vaccum, and analyzed for weight loss.

\section{Determination of the Biological Activities}

Materials. 4-5 week-old female Kunming mice were used. The soluble antigen from adult Schistosoma japonicum ( $\mathrm{SjAg}$ ) and complete Freund's adjuvant (CFA) were offered by Hubei Medical University.

Preparation of the complex of the polyphosphate (I) and SjAg. Particles of polyphosphate (I) with an average diameter of $10 \mu \mathrm{m}$ (made by colloidal mill) were dispersed in $0.1 \mathrm{M}$ PBS
( $\mathrm{pH}$ 7.0), and the adjuvant suspension was sterilized in the autoclave at $116^{\circ} \mathrm{C}$ for $15 \mathrm{~min}$ and stored at $4^{\circ} \mathrm{C}$. The complex of polyphosphate (I) and $\mathrm{SjAg}$ was prepared by mixing the adjuvant suspension and $\mathrm{SjAg}$ solution, the concentration of polyphosphate (I) and $\mathrm{SjAg}$ were adjusted to $5 \mathrm{mg} \mathrm{ml}^{-1}$ and $100 \mu \mathrm{g} \mathrm{ml}^{-1}$, respectively. The complex was stirred for $24 \mathrm{~h}$ at room temperature, and used to immunize the mice directly.

Immunization and Measurement of Antibodies. The animals were randomly divided into 3 groups, 25 animals in each group. Animals in groups $\mathrm{A}-\mathrm{C}$ received a subcutaneous, primary injection on day 0 , followed by two booster injections on days 14 and 21 . The primary injections were $50 \mu \mathrm{g} \mathrm{SjAg}$ in $0.1 \mathrm{ml}$ normal saline (NS) (group A, as negative control), $50 \mu \mathrm{g} \mathrm{SjAg}$ in $0.1 \mathrm{ml} \mathrm{CFA} \mathrm{(group} \mathrm{B,}$ as positive control), $50 \mu \mathrm{g} \mathrm{SjAg}+2.5 \mathrm{mg}$ polyphosphate (I) in $0.5 \mathrm{ml}$ PBS (group C). The booster injections were $20 \mu \mathrm{g} \mathrm{SjAg}$ in $0.1 \mathrm{ml} \mathrm{NS}$ (group A), $20 \mu \mathrm{g} \mathrm{SjAg}$ in $0.1 \mathrm{ml} \mathrm{CFA} \mathrm{(group}$ B), $20 \mu \mathrm{g} \mathrm{SjAg}+1 \mathrm{mg}$ polyphosphate (I) in $0.2 \mathrm{ml}$ PBS (group C).

Three animals in each group were bled every week, the serum samples were separated and combined, and stored at refrigerator $\left(-20^{\circ} \mathrm{C}\right)$. The antibody titers were measured by enzymelinked immunosorbent assay (ELISA).

\section{RESULTS AND DISCUSSION}

\section{Synthesis and Characterization of the Polyphos- phates}

The dipeptide monomers were prepared by the carbodiimide coupling method following the standard procedures of peptide chemistry. ${ }^{9}$ Their structures were ascertained by FT-IR, ${ }^{1} \mathrm{H}$ NMR, and elemental analysis (Tables I and II).

Polyphosphates were obtained by solution polycondensation using triethylamine as acid acceptor in dichloromethane at room temperature. The resulting polymers are slightly yellowish powder or wax-like solid, and have 
Table I. Experimental data on dipeptide monomers

\begin{tabular}{|c|c|c|c|c|c|}
\hline \multirow{2}{*}{ Compound } & \multirow{2}{*}{$\frac{\text { Yield }}{\%}$} & \multirow{2}{*}{$\frac{\mathrm{mp}}{{ }^{\circ} \mathrm{C}}$} & \multicolumn{3}{|c|}{ Elemental analysis $/ \%^{b}$} \\
\hline & & & $\mathrm{C}$ & $\mathrm{H}$ & $\mathrm{N}$ \\
\hline CTTH & 65 & $\begin{array}{c}154-155 \\
(154-156)^{\mathrm{a}}\end{array}$ & $\begin{array}{c}68.30 \\
(68.31)\end{array}$ & $\begin{array}{c}6.99 \\
(6.81)\end{array}$ & $\begin{array}{c}4.95 \\
(4.98)\end{array}$ \\
\hline CSTH & 72 & $107-108$ & $\begin{array}{c}63.87 \\
(64.18)\end{array}$ & $\begin{array}{c}7.12 \\
(7.08)\end{array}$ & $\begin{array}{c}5.58 \\
(5.76)\end{array}$ \\
\hline СТTP & 69 & $125-126$ & $\begin{array}{c}71.51 \\
(71.76)\end{array}$ & $\begin{array}{c}8.48 \\
(8.32)\end{array}$ & $\begin{array}{c}3.93 \\
(3.99)\end{array}$ \\
\hline CSTP & 75 & $101-103$ & $\begin{array}{c}69.25 \\
(68.95)\end{array}$ & $\begin{array}{c}8.40 \\
(8.68)\end{array}$ & $\begin{array}{c}4.33 \\
(4.47)\end{array}$ \\
\hline CTTS & 73 & $126-128$ & $\begin{array}{c}71.89 \\
(72.29)\end{array}$ & $\begin{array}{c}8.05 \\
(8.55)\end{array}$ & $\begin{array}{c}3.26 \\
(3.83)\end{array}$ \\
\hline CSTS & 78 & $105-107$ & $\begin{array}{c}69.97 \\
(69.69)\end{array}$ & $\begin{array}{c}8.96 \\
(8.93)\end{array}$ & $\begin{array}{c}3.93 \\
(4.28)\end{array}$ \\
\hline
\end{tabular}

${ }^{a} \mathrm{mp}$ reported in ref 5 .

b Figures in parentheses show calculated data.

Table II. Spectra of dipeptide monomers ${ }^{\mathrm{a}}$

\begin{tabular}{|c|c|c|}
\hline Compound & ${ }^{1} \mathrm{H}$ NMR $\left(\delta / \mathrm{ppm}\right.$, DMSO- $\left.d_{6}\right)$ & FT-IR $\left(\bar{v} / \mathrm{cm}^{-1}, \mathrm{KBr}\right.$ plate $)$ \\
\hline \multirow{7}{*}{ CTTS } & $0.9\left(3 \mathrm{H}, \mathrm{CH}_{3}\right)$ & $3478,3300(\mathrm{OH}, \mathrm{NH})$ \\
\hline & $1.0-1.6\left(32 \mathrm{H},\left(\mathrm{CH}_{2}\right)_{16}\right)$ & $2919,2850\left(\mathrm{CH}_{3}, \mathrm{CH}_{2}\right)$ \\
\hline & $2.8-3.4\left(4 \mathrm{H},-\mathrm{CH}_{2}-\mathrm{Ph}\right)$ & $1733,1697,1652$ \\
\hline & $3.8-4.4\left(4 \mathrm{H},-\mathrm{CH}_{2}-\mathrm{O},-\mathrm{N}-\mathrm{CH}-\mathrm{CO}-\right)$ & $(-\mathrm{COO}-,-\mathrm{CONH}-)$ \\
\hline & $4.9\left(2 \mathrm{H},-\mathrm{Ph}-\mathrm{CH}_{2}-\mathrm{O}-\right)$ & $1614,1536,1516,1440$ \\
\hline & $6.5-7.4(15 \mathrm{H}, \mathrm{Ph}-\mathrm{H}, \mathrm{Ph}-\mathrm{OH})$ & $(-\mathrm{CONH}-,-\mathrm{C}-\mathrm{N}-,-\mathrm{Ph}-)$ \\
\hline & $9.1,8.2(2 \mathrm{H},-\mathrm{CONH}-)$ & $1268,1234,1206,1085(-\mathrm{C}-\mathrm{O}-)$ \\
\hline \multirow{7}{*}{ CSTS } & $0.9\left(3 \mathrm{H}, \mathrm{CH}_{3}\right)$ & $3447,3260(\mathrm{OH}, \mathrm{NH})$ \\
\hline & $1.0-1.7\left(32 \mathrm{H},\left(\mathrm{CH}_{2}\right)_{16}\right)$ & $2919,2850\left(\mathrm{CH}_{3}, \mathrm{CH}_{2}\right)$ \\
\hline & $2.8-3.4\left(2 \mathrm{H},-\mathrm{CH}_{2}-\mathrm{Ph}\right)$ & $1738,1691,1657$ \\
\hline & $3.6-4.3\left(6 \mathrm{H},-\mathrm{CH}_{2}-\mathrm{O},-\mathrm{N}-\mathrm{CH}-\mathrm{CO}-\right)$ & $(-\mathrm{COO}-,-\mathrm{CONH}-)$ \\
\hline & $5.0\left(2 \mathrm{H}, \mathrm{Ph}-\mathrm{CH}_{2}-\mathrm{O}-\right)$ & $1538,1517,1470$ \\
\hline & $6.5-7.4(11 \mathrm{H}, \mathrm{Ph}-\mathrm{H}, \mathrm{Ph}-\mathrm{OH})$ & $(-\mathrm{CONH}-,-\mathrm{C}-\mathrm{N}-,-\mathrm{Ph}-)$ \\
\hline & $9.1,8.2(2 \mathrm{H},-\mathrm{CONH}-)$ & $1261,1243,1211,1045(-\mathrm{C}-\mathrm{O}-)$ \\
\hline
\end{tabular}

a As representative examples, the ${ }^{1} \mathrm{H}$ NMR and FT-IR spectra of CTTS and CSTS are listed here.

good solubility in methanol, THF, DMSO, and dichloromethane, but are insoluble in water, ether, hydrocarbons. Polyphosphate (II), (IV), and (VI) which contain serine residue were found to be more hygroscopic than polyphosphate (I), (III), and (V), respectively.

The structures of the polyphosphates were confirmed by FT-IR, ${ }^{1} \mathrm{H}$ NMR, and elemental analysis. The experimental data are listed in
Tables III and IV.

\section{Polymer Degradation in Vitro}

The polymers may be degraded in the presence of a nucleophile, such as the hydroxyl ion. Theoretically, water should cleave the phosphoester bond, yielding the dipeptide, alkanol, and phosphoric acid, as shown in eq 1 . 
Polymer Immunoadjuvants

Table III. Experimental data on polyphosphates

\begin{tabular}{|c|c|c|c|c|c|c|}
\hline \multirow{2}{*}{ Polyphosphate } & \multirow{2}{*}{ Appearance } & \multirow{2}{*}{$\frac{\text { Yield }}{\%}$} & \multirow{2}{*}{$\begin{array}{c}\bar{M}_{w} \\
\left(\times 10^{4}\right)\end{array}$} & \multicolumn{3}{|c|}{ Elemental analysis $(\%)^{a}$} \\
\hline & & & & $\mathrm{C}$ & $\mathrm{H}$ & $\mathbf{N}$ \\
\hline I & Yellowish powder & 63 & 1.89 & $\begin{array}{c}61.51 \\
(62.56)\end{array}$ & $\begin{array}{c}6.46 \\
(6.35)\end{array}$ & $\begin{array}{c}4.59 \\
(4.29)\end{array}$ \\
\hline II & Yellowish powder & 51 & 1.28 & $\begin{array}{c}57.02 \\
(58.32)\end{array}$ & $\begin{array}{c}6.95 \\
(6.47)\end{array}$ & $\begin{array}{c}4.62 \\
(4.86)\end{array}$ \\
\hline III & Yellowish powder & 71 & 0.91 & $\begin{array}{c}65.85 \\
(66.64)\end{array}$ & $\begin{array}{c}7.88 \\
(7.75)\end{array}$ & $\begin{array}{c}3.41 \\
(3.53)\end{array}$ \\
\hline IV & Yellowish wax-like solid & 75 & 1.31 & $\begin{array}{c}62.11 \\
(63.67)\end{array}$ & $\begin{array}{c}8.60 \\
(8.02)\end{array}$ & $\begin{array}{c}3.57 \\
(3.91)\end{array}$ \\
\hline $\mathrm{V}$ & Yellowish powder & 68 & 1.45 & $\begin{array}{c}66.55 \\
(67.29)\end{array}$ & $\begin{array}{c}8.22 \\
(7.98)\end{array}$ & $\begin{array}{c}3.33 \\
(3.41)\end{array}$ \\
\hline VI & Yellowish wax-like solid & 76 & 1.01 & $\begin{array}{c}62.69 \\
(64.49)\end{array}$ & $\begin{array}{c}8.56 \\
(8.25)\end{array}$ & $\begin{array}{c}3.06 \\
(3.76)\end{array}$ \\
\hline
\end{tabular}

a Parentheses show calculated data of elemental analysis.

Table IV. Spectra of polyphosphates ${ }^{a}$

\begin{tabular}{|c|c|c|}
\hline Polyphosphate & ${ }^{1} \mathrm{H}$ NMR $\left(\delta / \mathrm{ppm}, \mathrm{CDCl}_{3}\right)$ & FT-IR $\left(\bar{v} / \mathrm{cm}^{-1}, \mathrm{KBr}\right.$ plate $)$ \\
\hline I & $\begin{array}{l}0.9\left(3 \mathrm{H}, \mathrm{CH}_{3}\right) \\
1.0-1.4\left(11 \mathrm{H}, \mathrm{CH}_{3},\left(\mathrm{CH}_{2}\right)_{4}\right) \\
2.8-3,2\left(4 \mathrm{H},-\mathrm{CH}_{2}-\mathrm{Ph}\right) \\
3.6-4.4\left(6 \mathrm{H},-\mathrm{CH}_{2}-\mathrm{O},-\mathrm{N}-\mathrm{CH}-\mathrm{CO}\right) \\
5.2\left(2 \mathrm{H}, \mathrm{Ph}-\mathrm{CH}_{2}-\right) \\
6.6-7.4(15 \mathrm{H}, \mathrm{Ph}-\mathrm{H},-\mathrm{CO}-\mathrm{N}-)\end{array}$ & $\begin{array}{l}3302(\mathrm{~b},-\mathrm{NH}-) \\
2952,2932,2859\left(\mathrm{CH}_{3}, \mathrm{CH}_{2}\right) \\
1723,1679(-\mathrm{COO}-,-\mathrm{CONH}-) \\
1230,1216(\mathrm{~b}, \mathrm{P}=\mathrm{O},-\mathrm{C}-\mathrm{O}-) \\
1088,(\mathrm{P}-\mathrm{O}-\mathrm{C})\end{array}$ \\
\hline II & $\begin{array}{l}0.9\left(3 \mathrm{H}, \mathrm{CH}_{3}\right) \\
1.0-1.4\left(11 \mathrm{H}, \mathrm{CH}_{3},\left(\mathrm{CH}_{2}\right)_{4}\right) \\
2.8-3.2\left(2 \mathrm{H},-\mathrm{CH}_{2}-\mathrm{Ph}\right) \\
3.6-4.8\left(8 \mathrm{H},-\mathrm{CH}_{2}-\mathrm{O},-\mathrm{N}-\mathrm{CH}-\mathrm{CO}\right) \\
5.0\left(2 \mathrm{H}, \mathrm{Ph}-\mathrm{CH}_{2}-\right) \\
6.6-7.4(11 \mathrm{H}, \mathrm{Ph}-\mathrm{H},-\mathrm{CO}-\mathrm{NH}-)\end{array}$ & $\begin{array}{l}3330(\mathrm{~b},-\mathrm{NH}-) \\
2957,2932,2859\left(\mathrm{CH}_{3}, \mathrm{CH}_{2}\right) \\
1732,1680(-\mathrm{COO}-,-\mathrm{CONH}-) \\
1235(\mathrm{~b}, \mathrm{P}=\mathrm{O},-\mathrm{C}-\mathrm{O}-) \\
1093(\mathrm{P}-\mathrm{O}-\mathrm{C})\end{array}$ \\
\hline
\end{tabular}

a As representative examples, the ${ }^{1} \mathrm{H}$ NMR and FT-IR spectra of polyphosphate (I) and (II) are listed.

$$
\begin{gathered}
\stackrel{\mathrm{O}}{\|} \\
\left(\mathrm{O}-\mathrm{R}^{1}-\mathrm{O}-\stackrel{\mathrm{P}}{\mathrm{I}}\right)+\mathrm{H}_{2} \mathrm{O} \rightleftharpoons \\
\mathrm{OR}^{2}
\end{gathered}
$$

As a representative example, a degradation study on polyphosphate (I) in different media is shown in Figure 2. As expected, hydrolysis was base catalyzed. The degradation rate is considerably faster in alkali medium than that in neutral or acidic medium.

The rate of degradation could be influenced by the character of the side chain and hydrophilicity of the polymer backbone. The results of in vitro degradation studies conducted in $\mathrm{pH} 7.4 \mathrm{PBS}(0.1 \mathrm{M})$ at $37^{\circ} \mathrm{C}$ are shown in Figure 3. The polyphosphates with a L-Ser-LTyr recurring unit degraded much faster. The polyphosphate (II), (IV), (VI), and (I) swelled quickly, and changed dramatically in shape. The disc of polyphosphate (II), the most hydrophilic, nearly disappeared on the third day. It is concluded from Figure 3 that greater cleavage of the phosphoester bonds occurrs in 


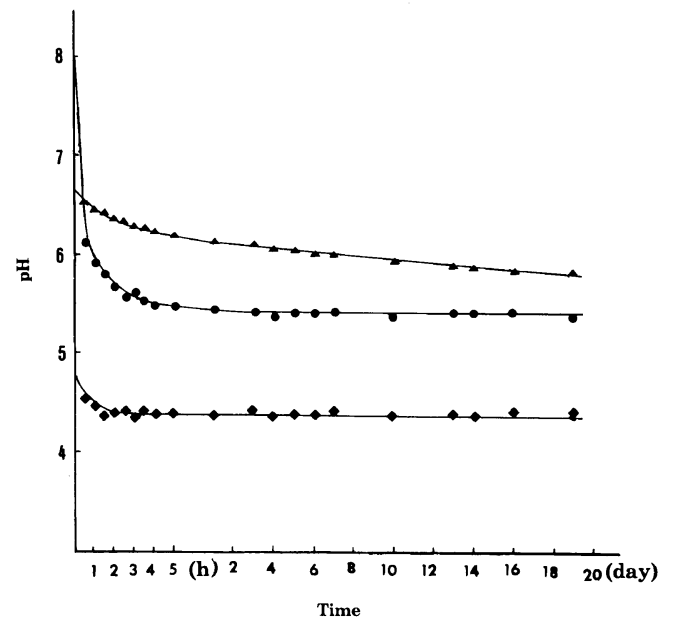

Figure 2. In vitro degradation of polyphosphate (I) in different $\mathrm{pH}$ medium.

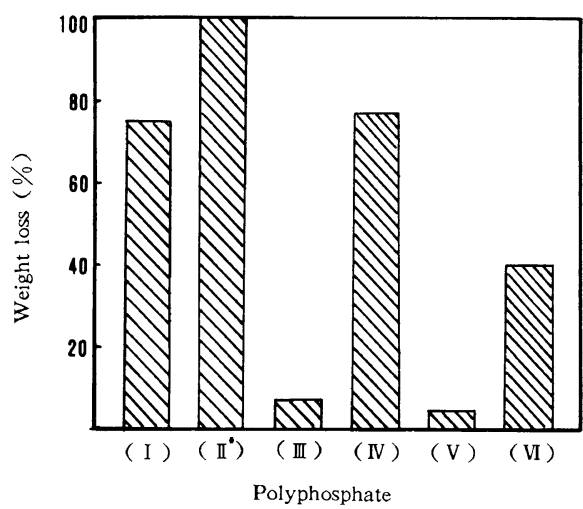

Figure 3. In vitro degradation of polyphosphates (I) (VI) in PBS $\left(0.1 \mathrm{M}, \mathrm{pH} 7.4,37^{\circ} \mathrm{C}\right){ }^{*}$ The weight loss of polyphosphate (II) is estimated to be $100 \%$ by the first three days.

polymers where water penetrates more readily, and the polyphosphates with long alkyl chains are more stable to cleavage and degradation.

\section{Biological Study}

The soluble antigen extracted from adult Schistosoma japonicum ( $\mathrm{SjAg}$ ) was chosen for testing adjuvanticity. Antibody response was measured as antibody titers to $\mathrm{SjAg}$ in female mice over 10 weeks. Figure 4 shows the antibody titers for each of the experimental groups.

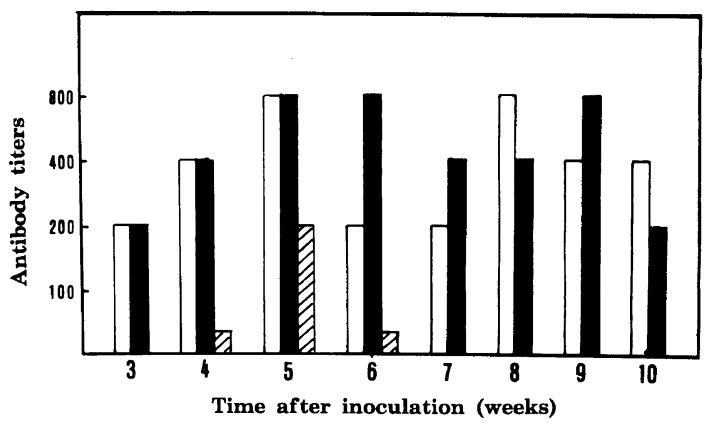

Figure 4. Antibody titers as determined by ELISA. Group C, SjAg complexed with polyphosphate (I); Group B, SjAg in CFA (as positive control); Group A, $\mathrm{SjAg}$ in NS (as negative control).

It is evident that, $\mathrm{SjAg}$ complexed with polyphosphate (I), results in as a high antibody response as that of $\mathrm{SjAg}$ in complete Freund's adjuvant (CFA).

In conclusion, new biodegradable and biocompatible polyphosphates containing LTyr-L-Tyr or L-Ser-L-Tyr dipeptide were synthesized by solution polycondensation. A preliminary biological test indicated the polyphosphate (I) to possess strong adjuvant activity.

Acknowledgements. The support of this work by the National Natural Science Foundation of China is gratefully acknowledged. The authors thank Dr. Ming-Sen Jiang, Mr. Bai-Song Mei, and Mr. Ya-Ping Fu (Hubei Medical University, Wuhan) and Mr. JiangNing Wu (Wuhan University) for their help in the biological research.

\section{REFERENCES}

1. H. S. Warren and L. A. Chedid, CRC Crit. Rev. Immun., 8, 83 (1988).

2. I. Preis and R. S. Langer, J. Immunol. Methods, 20, 193 (1979).

3. J. Kohn, S. M. Niemi, E. C. Albert, J. C. Murphy, R. Langer, and J. G. Fox, J. Immunol. Methods, 95, 31 (1986).

4. S. Penczek, G. Lapienis, and P. Klosinski, Pure Appl. Chem., 56, 1309 (1984).

5. M. Richards, B. I. Dahiyat, D. M. Arm, P. R. Brown, 


\section{Polymer Immunoadjuvants}

and K. W. Leong, J. Biomed. Mater. Res., 25, 1151 (1991).

6. J. Kohn and R. Langer, J. Am. Chem. Soc., 109, 817 (1987).

7. W. Konig and R. Geiger, Chem. Ber., 103, 788 (1970).
8. B. C. Saunders, G. J. Stacey, F. Wild, and I. G. E. Wilding, J. Chem. Soc., 699 (1948).

9. M. Bodanszky and A. Bodanszky, "The Practice of Peptide Synthesis," Springer-Verlag, New York, N.Y., 1984, p 145. 